Vidya Wertta Volume 3 Nomor 2 Tahun 2020

p-ISSN 0852-7776-e-ISSN 2655-7282

https://ejournal.unhi.ac.id/index.php/vidyawertta

\title{
REJANG RENTENG BENTUK KESETARAAN GENDER DALAM RUANG SENI SAKRAL DI KOTA DENPASAR
}

\author{
Ni Luh Wiwin Astari \\ putuwiwinastari@gmail.com \\ Made Sugiarta \\ dekolehajus@hmail.com
}

Fakultas Pendidikan Universitas Hindu Indonesia

\begin{abstract}
ABSTRAK
Isu tentang kesetaraan gender sampai saat ini masih terus diperbincangkan. Hal ini sebagai bentuk upaya mengangkat kesejajaran antara laki-laki dengan perempuan dalam berbagai sektor. Artikel ini berupaya mengangkat Rejang Renteng hubungannya dengan kesetaraan gender. Sebagaimana diketahui, peran perempuan dalam ruang sakral selalu berada dalam posisi minor. Bahkan dalam ruang agama sendiri, laki-laki selalu memainkan peran yang lebih besar daripada perempuan. Tidak begitu dalam seni sakral di Bali. Tarian rejang Renteng semakin menjadi trend pementasan saat ini. Tarian yang gerakannya klasik dan sederhana ini selalu menyedot perhatian penontonnya. Semakin maraknya pementasan Rejang Renteng dalam pelaksanaan upacara yadnya di Bali membuktikan eksistensi perempuan dalam ruang-ruang seni khususnya yang berhubungan dengan agama.

Kata Kunci : Rejang Renteng, Gender, Seni Sakral
\end{abstract}




\begin{abstract}
The issue of gender equality is still being discussed. This is an effort to raise the parallels between men and women in various sectors. This article seeks to raise the Rejang Renteng warning with gender equality. As is well known, the role of women in the sacred space is always in a minor position. Even in the religious space itself, men always play a bigger role in women. Not so in sacred arts in Bali. Renteng's rejang dance is increasingly becoming a current staging trend. This dance, whose movements are classic and simple, always attracts the attention of the audience. The increasing number of Rejang Renteng performances in the implementation of the yadnya ceremony in Bali proves the existence of women in art spaces related to religion.
\end{abstract}

Keywords: Rejang Renteng, Gender, Sacred Art

\title{
I. PENDAHULUAN
}

Pembahasan terkait dengan kesetaraan gender sampai saat ini masih terus diperbincangkan. Ini sebagai bentuk upaya mengangkat kesejajaran antara laki-laki dengan perempuan dalam berbagai sektor. Kata gender berasal dari bahasa Inggris yang berarti jenis kelamin (John M. echols dan Hassan Sadhily, 1983: 256).Secara umum, pengertian gender adalah perbedaan yang tampak antara laki-laki dan perempuan apabila dilihat dari nilai dan tingkah laku. Dalam Women Studies Ensiklopedia dijelaskan bahwa gender adalah suatu konsep kultural, berupaya membuat perbedaan (distinction) dalam hal peran, perilaku, mentalitas, dan karakteristik emosional antara laki-laki dan perempuan yang berkembang dalam masyarakat.

Ahimsha Putra (2000) menyatakan bahwa istilah gender dapat dibedakan ke dalam beberapa pengertian berikut ini: gender sebagai suatu istilah asing dengan makna tertentu, gender sebagai suatu fenomena sosial budaya, gender sebagai suatu kesadaran sosial, gender sebagai suatu persoalan sosial budaya, gender sebagai sebuah konsep untuk analisis, gender sebagai sebuah perspektif untuk memandang kenyataan.

Dalam Wikipedia Bahasa Indonesia dijelaskan, gender merupakan aspek hubungan sosial yang dikaitkan dengan diferensiasi seksual pada manusia. Gender dipahami sebagai suatu konsep mengenai peran laki-laki dan perempuan di suatu masa dan kultur tertentu yang dikonstruksi. Hal ini merupakan hasil bentukan ketentuan kehidupan sosial bukan biologis. Gender mengacu ke peran perempuan 
dan laki-laki yang dikonstruksi secara sosial. Peran tersebut dipelajari berubah dari waktu ke waktu dan beragam menurut budaya dan antar budaya.

Namun demikian kesetaraan sepertinya samar-samar dilaksanakan dalam kehidupan sehari-hari. Alasannya karena prinsip-prinsip kesetaraan dijabarkan dalam konteks sosio-historis tertentu, dan adanya bias gender (kelaki-lakian) di dalam penafsiran agama yang selama ini didominasi oleh kaum laki-laki. Isu gender yang pada mulanya berasal dari worldview Barat ternyata juga sudah merambah dalam ruang lingkup kajian agama.

Timbulah beberapa pertanyaan dan tingkah laku keagamaan yang belum pernah terjadi sebelumnya. Salah satu contoh yang dapat kita amati adalah dalam ruang Agama yang menjadi pemimpin dalam persembahyangan didominasi oleh kaum laki-laki, hanya dengan pengecualian saja perempuan mendapat kesempatan untuk mendapatkan posisi itu. Bila kita merujuk kepada sastra bahwa dihadapan tuhan semua mahluk diciptakan sama. Perempuan seringkali ragu untuk melawan ketidakadilan, baik yang dilakukan oleh masyarakat maupun suaminya sendiri karena doktrin dan pemikiran agama yang dianggap sakral dan tidak boleh dilawan.

Kehadiran Tari Rejang Renteng saat ini menjadi salah satu fenomena dalam ruang seni sakral. Tentunya ini akan menjadi angin segar bagi perempuan sebab kemunculan tarian ini memberikan jawaban bahwa seni sakral juga mampu memberikan ruang ekspresi bhakti pada perempuan dalam kegiatan keberagaaman Hindu di bali. Tari Rejang adalah sebuah tarian klasik (tradisional) yang gerak-gerak tarinya sangat sederhana (polos), lemah gemulai, yang dilakukan secara berkelompok atau massal, dan penuh dengan rasa pengabdian kepada leluhur.

Tari ini dilakukan oleh para wanita di dalam mengikuti persembahyangan dengan cara berbaris, melingkar, dan sering pula berpegangan tangan. Biasanya, Tari Rejang menggunakan pakaian adat atau pakaian upacara, menggunakan hiasan bunga-bunga emas di kepalanya sesuai dengan pakaian adat daerah masing-masing. Tarian ini masih dapat dilihat di beberapa daerah di Bali, bahkan kebanyakan desa memiliki kelompok yang memang difokuskan untuk pertunjukan ini.

Maraknya kemunculan penari Rejang Renteng di tiap-tiap desa tidak hanya memberikan ruang bhakti kepada umatnya namun lebih dari itu bahwa perempuan juga mampu menunjukan eksistensinya pada ruang seni sakral dalam Agama Hindu. Demikian juga sebaliknya bahwa Agama Hindu di Bali cukup memperhatikan kesetaraan gender anatara perempuan dan juga laki-laki kendatipun hal tersebut berada diwilayah yang sangat privat. Isu inilah yang akan diangkat dalam artikel ini.

\section{METODE PENELITIAN}

Penelitian tentang Rejang Renteng sebagai bentuk kesetaraan gender ini menggunakan rancangan penelitian secara kualitatif. Sumber data primernya 
meliputi hasil wawancara, berupa ungkapan dan pernyataan, sementara data sekunder berupa literatur. Teknik pengumpulan data meliputi observasi, wawancara dan studi dokumen. Analisa data dilakukan dengan teknik analisis kualitatif. Penyajiannya lebih cenderung deskriptif dan interpretatif.

\section{PEMBAHASAN}

\subsection{Perempuan dalam Kehidupan Sosial}

Bungin dalam (Utama, 2013:140) menjelaskan manusia pada dasarnya tidak mampu hidup sendiri dalam dunia ini baik sendiri dalam konteks fisik maupun dalam konteks sosial budaya. Terutama dalam konteks sosial budaya manusia memerlukan manusia lain untuk dapat saling bekerja sama dalam pemenuhan kebutuhan fungsifungsi sosial satu dengan yang lainnya. Pada dasarnya, perempuan sebagai makhluk individu merupakan bagian dan unit terkecil dari kehidupan sosial atau perempuan sebagai makhluk sosial yang membentuk suatu kehidupan masyarakat.

Syahrun (Sadulloh, 2009:81) menyatakan bahwa setiap orang bertanggung jawab atas dirinya, atas pikiran, perasaan, pilihan, dan perilakunya. Orang yang betul-betul manusia adalah orang yang bertanggung jawab penuh. Tidak ada orang lain yang mengambil alih tanggung jawab dalam hidupnya. Kata hatinya adalah kata hatinya sendiri. Perempuan sebagai individu tentunya memiliki perasaan untuk dapat disejajarkan dengan laki-laki dalam berbagai aspek tak terkecuali dalam kehidupan beragama tentunya mereka akan merasa mendapatkan penghormatan jika masuk kedalam ruang-ruang tertentu dalam kehidupan beragama.

Sebagai mahluk sosial, perempuan menginginkan keadilan dan persamaan peran dalam segala dimensi kesehariannya, seperti keadilan di bidang pendidikan, ekonomi, dan sosial. Tuntutan ini adalah wajar, mengingat dimensi sosial dan di posisi jabatan manajer perempuan sering kali tersubordinasi (Triguna, 2002: 16). Padahal secara normatif negara telah menjamin persamaan antara laki-laki dan perempuan untuk berpartisipasi dalam pembangunan.

Perempuan, baik sebagai warga negara maupun sebagai sumber daya manusia mempunyai hak dan kewajiban serta kesempatan yang sama dengan laki-laki dalam pembangunan di segala bidang (Suriani, 2003:41). Kehadiran rejang renteng tentu sebagai upaya perempuan untuk tetap berada diruang sosial, sebagai bentuk sosialisasi dalam kehidupan tidak hanya dalam rangka menjalin kehangatan dalam proses interaksi sosial namun juga kepada pengembangan diri. 


\subsection{Kesetaraan Gender dalam Sastra Hindu}

Agama Hindu memberikan pandangan yang cukup positif terhadap kesetaraan gender ini, nampak antara laki-laki digambarkan tanpa ada unsur perbedaan dalam artian perempuan kedudukannya setara dengan laki-laki. Dalam beberapa kitab suci Weda, memuat sloka-sloka yang menyatakan pembagian antara tugas antara suami dan istri (Wandri,2006:2). Lebih lanjut dikatakan suami sebagai keluarga wajib mencari nafkah untuk memenuhi keperluan rumah tangga, sedangkan istri wajib mengurus keperluan rumah tangga serta mewujudkan kehidupan rumah tangga yang harmonis sehingga terciptalah kehidupan yang bahagia dan sejahtra (Wandri 2006:2).

Hal ini menunjukkan bahwa pembagian tugas tersebut merupakan sebuah upaya kerjasama antara perempuan dan laki-laki. Hal ini tentunya sangat logis mengingat secara biologis perempuan berperan untuk membesarkan anaknya melalui air susu ibu (ASI). Secara kodrati dalam membina sebuah keluarga yang sejahtera tentunya pembagian peranan tersebut sangat seimbang sehingga tidak terjadi tumpeng tindih antara laki-laki dan juga perempuan.

Wanita berasal dari Bahasa Sanskrit, yaitu Svanittha, di mana kata Sva artinya "sendiri" dan Nittha artinya "suci". Jadi Svanittha artinya "mensucikan sendiri" kemudian berkembang menjadi pengertian tentang manusia yang berperan luas dalam Dharma atau "pengamal Dharma". Selanjutnya, dalam kedudukannya perempuan mendapatkan tempat terhormat, hal ini di jelaskan dalam kitab Manava Dharmasastra III ; 56 menyatakan bahwa :

Yatra naryastu pujyante, Ramante tatra devatah, Yatraitastu na pujyante, sarvastatraphalah kriyah.

Artinya : Di mana wanita dihormati, di sanalah pada Dewa-Dewa merasa senang, tetapi di mana mereka tidak dihormati, tidak ada upacara suci apapun yang akan berpahala.

Konsepsi terciptanya manusia ini sudah tergambar bahwa laki dan perempuan secara azas harkat dan martabat serta gendernya adalah sejajar. Perbedaan laki dan perempuan itu adalah perbedaan yang komplementatif artinya perbedaan yang saling lengkap melengkapi. Tanpa perempuan laki-laki itu tidak lengkap. Demikian juga sebaliknya tanpa laki-laki perempuan itu disebut tidak lengkap.

Hal ini dikarenakan manusia memang merupakan mahluk sosial dan saling membutuhkan antara laki-laki dan perempuan menunjukkan adanya kesetaraan antara keduanya (Artatik, 2013:51). Hal ini memberikan sebuah gambaran bahwa 
dalam Agama Hindu perempuan pun seyogyanya dapat mendapatkan peluang yang sama dalam menunjukan rasa bakti kehadapan Ida Sang Hyang Widi Wasa. Melalui rejang renteng cetusan rasa bhakti semakin terbuka lebar bagi perempuan.

\subsection{Kesetaraan dalam Rejang Renteng}

Budaya merupakan hasil olah pikiran manusia yang terefleksi dalam tiap kehidupan. Secara tidak sadar kebudayaan-kebudayaan yang terbentuk juga cenderung memberikan marginalisasi pada peranan perempuan, hasil kebudayaan juga menempatkan peran dan perilaku tertentu yang berbeda untuk laki-laki dan perempuan. Kontruksi sosial budaya yang melekat pada ciri fisik menempatkan perempuan sebagai lemah lembut, sosial, dan pengelola rumah tangga (Sumarti 2015:293). Tentunya hal inilah yang disebut sebagai masalah sosial. Sesungguhnya masalah-masalah sosial merupakan bagian yang tidak terpisahkan dari kehidupan manusia itu sendiri karena maslaha sosial telah terwujud dalam masyarakat sebagai hasil kebudayaan itu sendiri (Agusta, 2015:65). Salah satunya adalah budaya patriarki yang telah berlangsung sejak lama.

Patriarki berasal dari kata patriarkat, berarti struktur yang menempatkan peran laki-laki sebagai penguasa tunggal, sentral, dan segala-galanya. Sistem patriarki yang mendominasi kebudayaan masyarakat menyebabkan adanya kesenjangan dan ketidak adilan gender yang mempengaruhi hingga ke berbagai aspek kegiatan manusia (Sakina 2013:72). Praktik budaya patriarki masih berlangsung hingga saat ini, ditengah berbagai gerakan feminis dan aktivis perempuan yang gencar menyuarakan serta menegakkan hak perempuan (Sakina 2013: 72).

Pensubordinasian terhadap perempuan dianggap telah menjadi sesuatu yang struktural dan digambarkan sebagai sebuah budaya patriarki. Di Negara Indonesia sendiri, memperlihatkan mengenai kedudukan seorang laki-laki lebih tinggi dibandingkan perempuan. Sejarah nasional pun menguak sebuah fakta dimana kaum perempuan tidak diperbolehkan untuk menempuh pendidikan (kecuali perempuan tersebut berasal darikalangan priyayi atau bangsawan), apalagi memiliki sebuah profesi diluar rumah atau ikut berpartisi pasi dalam birokrasi. Maka, muncul gerakan dari seorang bangswan kelahiran Jepara, R.AKartini yang memperjuangkan emansipasi perempuan di bidang pendidikan (Sakina, 2013:75).

Budaya patriarki yang telah ada dalam selang waktu yang cukup lama seiring berjalannya waktu sudah tidak dipandang sebagai sebuah ketimpangan namun lebih dipandang sebagai sebuah fakta ilmiah artinya adalah sesuatu yang boleh dan tidak boleh dilakukan oleh laki-laki dan perempuan merupakan faktor alamiah yang sudah melekat pada laki-laki dan perempuan. Kehidupan kesenian yang selama ini di dominasi oleh laki-laki dengan keberadaan rejang renteng sedikit tidaknya 
perempuan juga mendapatkan ruang dalam proses kesenian terlebih dalam kesenian sakral.

\section{PENUTUP}

Umat Hindu di Bali memiliki berbagai macam jenis kesenian tari yang dipentaskan saat upacara yadnya. Salah satu yang sedang populer adalah rejang renteng. Berdasarkan kajian, Rejang Renteng yang sedang digemari menunjukkan sebuah kesetaraan gender di ruang seni. Sebagaimana diketahui, peran perempuan dalam ruang sakral selalu berada dalam posisi minor. Bahkan dalam ruang agama sendiri, laki-laki selalu memainkan peran yang lebih besar daripada perempuan. Tidak begitu dalam seni sakral di Bali. Tarian rejang Renteng semakin menjadi trend pementasan saat ini. Tarian yang gerakannya klasik dan sederhana ini selalu menyedot perhatian penontonnya. Semakin maraknya pementasan Rejang Renteng dalam pelaksanaan upacara yadnya di Bali membuktikan eksistensi perempuan dalam ruang-ruang seni khususnya yang berhubungan dengan agama.

\section{DAFTAR PUSTAKA}

Adi, D K. 2001. Kamus Praktis Bahasa Indonesia.Surabaya:Fajar Mulya.

Ahimsa-Putra, Heddy Shri. 2006. Strukturalisme Levi-Strauss Mitos dan Karya Sastra. Cetakan

pertama. Yogyakarta: Kepel Press.

Anwar Syarifudin, MA. 2010. Metode Penelitian. Pustaka Pelajar.

Arniati, Ida Ayu Komang. 2008. Pandangan Gender Pada Smerti Dalam Perkembangan Modern. Surabaya: Paramita

Bhasya of Sayanacarya, Penterjemah Suastawan dkk, 2005. Atharvaveda. Surabaya: Penerbit Paramita.

John M. Echols dan Hassan Shadily,(20030 Kamus Inggris-Indonesia, Gramedia, Jakarta, 1983

Maswinara, I Wayan. 1999. Weda Sruti Rgveda, Samhita Saskala Sakha Mandala I, II, III.Surabaya: Penerbit Paramita.

Moleong, J Lexi.2010. Metodologi Penelitian Kualitatif. Bandung : Rosda Karya PHDI.1985.Himpunan Keputusan Seminar Kesatuan Tafsir Terhadap Aspek-Aspek Ngafifi mumahad, kemajuan teknologi dan pola hidup manusia dalam perspektif sosial

budaya,jurnal pembangunan pendidikan, vol 2 no 1 tahun 2014 hal 33-47 
Pudja Gd, dan Tjok Rai Sudharta.78/79. Manawa Dharmaçastra. Jakarta: Departemen Agama Republik Indonesia.

Pendit, S. Nyoman. 1986. Bhagawadgita. Jakarta: Penerbit Dharma Nusantara. Negara.

Sadulloh Uyoh, dkk. 2007. pedagogik. Bandung: Cipta Utama.

Suhardi, Untung; Kedudukan Perempuan Hindu dalam Kitab Sarasamuccaya; 2015; Paramita;

Surabaya

Suhardi \& Sunarti S. (2009). Sosiologi 2. Bandung: Pusat Perbukuan Departemen Pendidikan

Nasional

Sugiyono.2010. Metode Penelitian Kuantitaif kualitatif dan $R \& D$.Bandung : Alfabeta

Suryani, Luh Ketut. 2003. Perempuan Bali Kini. Denpasar: BP.

Saridewi, Desak Putu. 2014. Artikel Desain Diri Bagi Wanita Hindu Pada Era Modern Di Nusa Tenggara Barat. Mataram: STAHN Gde Pudja Mataram

Tim penyusun. 2005. Pengarusutamaan Gender (PUG) Menurut Agama Hindu. Surabaya: Paramita.

Wirawan, I Wayan Ardhi. 2015. Makalah "Pendidikan Perempuan Menurut Ajaran Hindu Dan Dalam Praktik Budaya Bali. Mataram: STAHN Gde Pudja Mataram

Wandra, Ni Wayan dan Ni Made Sukrawati. 2008. Materi Pokok Acara Agama Hindu.

Jakarta: Direktorat Jenderal Bimbingan Masyarakat Hindu Depatemen Agama RI.

I Wayan Widana, Ketidakadilan Gender dalam Tafsir Hindu : Sebuah Pengantar Gerakan Keadilan Gender dalam Perspektif Hindu,

Yudha, IBG. Triguna, M.S.(2013) SwastikaranaPedomanAjaran Agama Hindu, Jakarta: PT. Mabhakti . 